including some of Falconer's original specimens of the Siwalik fossil remains of animals. The herbarium, such as it was, occupied a very subordinate position of the Museum; for, as the specimens were unarranged, unmounted, and for the most part unnamed, the collection could not in that condition be considered of any practical use to the public. The material consisted mainly of specimens collected by natives employed by Dr. Jameson during his tours in connection with tea culture. There were also a few bundles of specimens collected by Royle and Falconer in various parts of North-West India and labelled in their own handwriting. These, however, were mere remnants and scraps of their original collections."

Reference to Mr. Parker's article must be made for a study of the methods by which Duthie grappled with the position and built up the magnificent herbarium, ultimately to prove so firm a foundation upon which the Dehra Dun Forest Research Institute could build.

Reference has been made to the Dehra Forest School Herbarium. This was started by $\mathrm{Mr}$. Gamble, who became director of the School in 1890 and held the position for some ten years. To start this collection, Gamble presented a set of his own duplicates collected in Bengal and Madras. $\mathrm{He}$ collected assiduously during his stay at Dehra and received many contributions from forest officers and others. Duthie also contributed, and the in- structors at the School, especially Upendra Nath Kanjilal and Birbal, collected many species of local trees and shrubs. Some private herbaria made by forest officers were also presented.

Mr. Parker details some interesting facts in connexion with the earlier collectors and their direct or indirect influence on the present herbarium at Dehra Dun. The names include Roxburgh, Wallich, Strachey, Winterbottom, Griffith, Helfer, Hooker fils, Thomson, Stocks, Dalzell (Bombay), Wight (South India), Thomson, Beddome (conservator of forests, Madras and Bombay), Falconer, and Jameson. Amongst later collectors are the names of Col. Davidson, R.E. (Kumaon), Dr. Aitcheson (Punjab and Afghanistan), Dr. Goodenough (collection received from Kew), Sir D. Brandis (greater part of herbarium received from Kew), Thwaites (Ceylon), Gamble, Lace (Punjab, Baluchistan, Burma), Sir H. Collett (Simla, NorthWest Frontier, and Upper Burma), C. B. Clarke, C. F. Elliott (conservator of forests, Punjab and North-West Frontier), A. V. Munro (conservator of forests, Hazara, Multan, Baluchistan), C. W. Hope (many ferns), W. Gollan (superintendent of the Botanic Gardens, Saharanpur, 1887-1904-many plants and mosses), W. A. Talbot (conservator of forests-Bombay plants), Cooke (College of Science, Poona), and Dr. Lisboa (grasses). The Herbarium also contains series of plants obtained by foreign exchanges.

\title{
Intelligence and Fertility.*
}

\section{By Dr. Shepherd Dawson.}

$\mathrm{I}^{\mathrm{N}}$ VESTIGATIONS have recently been carried out in Glasgow into the relationship between birth-rate and intelligence. Individual Binet tests were given to more than twelve hundred children of ages three to fourteen years, and the results of these tests have been correlated with the size of the family to which each child belonged. The population studied was slightly below average both socially and intellectually; among the fathers of the children there was a high proportion of labourers, and the average intelligence ratio of the children themselves was about ten per cent below the average of the general population.

Most previous investigations have been concerned with birth-rates only. In the present inquiry, information was collected also regarding fatalities and survivals; as regards the family to which a child belonged, there was a record of the number of children alive, the number of fatalities (ante-natal, natal, and post-natal), the ages of the children and the parents, and the number of years the latter had been married.

Correlations were calculated between the intelligence of the child and $(a)$ the number of surviving children in the family to which he belonged, $(b)$ the number born alive, $(c)$ the number of births, and $(d)$ the number of possible lives. The correlations were all negative and small, but significant,

* Substance of a paper read before Section $J$ (Psychology) of the British Association in London on Sept. 24.

No. 3249 , VoL. 129] that is, they showed a tendency for dull children to belong to larger families; they were slightly higher when only those families were considered in which the age of the mother was forty-five years or more, and the family presumably complete.

By dividing the children into three groups, 'bright', 'average', and 'dull', with intelligence ratios above 114, 114 to 85 , and below 85 (100 being the normal), it has been shown that the birthrate in the 'dull' group is about 50 per cent higher than in the 'bright', while in the 'average ' group it is about 35 per cent higher. The fatalities (antenatal, natal, and post-natal) are most numerous in the dullest families and fewest in the brightest; yet, in spite of this, the proportions of survivors at the time of the examination remained about the same ; there were about 50 per cent more 'dull' than 'bright', and about 40 per cent more 'average ' than 'bright'. In the completed families the differences were greater.

The dullest children obviously came from the largest families. If it be assumed, as is commonly done, that, on the whole, the intelligence of children is like that of their parents, then the dull parents have, on the whole, slightly more children than brighter parents.

The question how far these results are representative of what is happening in the population as a whole is clearly of importance. There is ground for thinking that in a group which contains a higher 
proportion of brighter intellects, the difference between the 'dull' and the 'bright' in respect of size of family may be greater, especially if sterility also be considered. An inquiry made some years ago in Glasgow into mortality-rates in 1789 poor families and 455 that were well-to-do, showed that when only families of more than one child were included, the average number of possible lives in the former was $5 \cdot 6$, while among the well-to-do it was 3.2. 'Well-to-do' and 'intelligent' are not synonymous terms, but there is a correlation between intelligence and social position, at any rate, up to the professional grade. Galton's inquiries into the family histories of 180 Englishmen who had distinguished themselves in science pointed in the same direction; the average size of the completed families of these men of distinction was almost exactly the same as that of the 'bright' Glasgow group.

These observations, then, show conclusively that the birth-rate is highest among the dullest members of the community, and that, in spite of their higher fatalities, they appear to be leaving a larger proportion of survivors, for at the time of the examination there was a higher average of surviving children in the dull and average groups than in the other. It is a problem for the future to determine what proportion of the children in each group will reach maturity and establish families of their own, for, unless there is a much higher fatality-rate among the present survivors of the duller groups, it is clear that the less intelligent elements of the population are increasing at a greater rate than the more intelligent.

The problem is one of national importance, for, although a slight difference, even a difference of one, between the families of the 'bright' and the 'dull' may seem a small matter, it is really serious, for the influence of a differential birth-rate is prob- ably cumulative, since people of the same intellectual grade tend to intermarry, and there is the possibility that the fertility of each grade may remain the same from one generation to another.

The only source of consolation in the dismal picture is the consciousness of our profound ignorance of some of the important factors in the situation. We have still to find the proportion of children of each grade of intelligence who survive to establish families of their own; we have to find to what extent the dull and the bright intermarry, and whether the fertility of each group remains constant. It is well known that superior intellects sometimes spring from apparently mediocre stock, but we still require exact information regarding the extent to which they pass on their brilliance to their children; the common belief is that able parents have, on the whole, gifted children, that mental capacity is inherited like stature and other physical characters. Also there are different kinds of dullness to be distinguished, dullness that is the result of pathological conditions, accident and disease, and dullness that is the result of traits inherent in the stock, and we are very much in need of methods of distinguishing these and assessing their incidence.

There is, however, clear evidence that the duller elements of society have bigger families than the more gifted, and the little we know about the fatalities among them suggests that dullness is being bred rather than intellect. In view of the tendency of the State and private enterprise to do so much for the unfit, it is obvious that the question of the relationship between intellect and birthrate is of more than academic importance and requires careful study, not only of the facts regarding birth-rate and survival, but also of the laws of mental inheritance, for, until these are known, speculation on methods of treatment is somewhat futile.

\section{Intellectual Co-operation.}

MONG the subjects considered by the Executive A Committee of the International Committee on Intellectual Co-operation at its thirteenth session last July, was a report from the Committee of Scientific Advisers appointed in April. This Committee had discussed the general question of the manner in which international intellectual cooperation can assist the co-ordination or organisation of scientific work, and had surveyed the various scientific matters which had already come before the International Committee.

The latter included a scheme of Prof. Cramer for the organisation of the documentation of chemistry, which the Committee of Scientific Advisers considered is primarily a question for the International Union of Chemistry, and in the field of bibliography the Committee limited itself to recommendations that authors' analytical summaries should be provided with all papers in scientific journalsa subject discussed elsewhere in this jssue (p. 181) -and that, in agreement with the scientific unions, national centres for scientific bibliography should be established where they do not already exist.
A proposal from the French National Committee regarding the unification of scientific terminology was regarded as within the competence of the scientific unions unless the latter should desire to utilise the relations already established between them and the International Committee. Similarly, the Committee of Scientific Advisers in its report endorsed the resolution of the Committee of Library Experts on the standardisation of printed publications. In view of the great advantages offered to the whole of the scientific world by the adoption of uniform rules for the classification of printed works and their utilisation, the immediate adoption of a standard format for periodicals and a bibliographical cover note was recommended.

The present financial position of the fund for the publication of Tables of Constants and Numerical Data was considered, and the great value of this publication was stressed. To assist in the solution of existing difficulties, an agreement between the International Committee on Tables of Constants and the Unions of Chemistry and Physics regarding the scientific and material 